\title{
Development of New Meat Product Technology via Tea Plants Application
}

\author{
E.L. Sahakyan, H.S. Sargsyan \\ Armenian National Agrarian University \\ emmass@list.ru, sargsyanhayk590@gmail.com
}

\section{A RT I CLE IN FO}

\section{Keywords:}

smoked/cured product,

poultry meat,

tea plants,

technology,

innovation

\begin{abstract}
A B S T RA C T
The aim of the current research is to develop a new technology for smoked/ cured meat production from the poultry meat, while reducing the ageing period and supplementing the product with proteins and carbohydrates needed for the regular life activity of human organism.

To this end we have developed a technology for manufacturing new variety of smoked product via the use of herbaceous plants, which reduce the ageing times of cured meat in 2 times.

The recipe and technological phases for the new type of smoked product manufacture was established. Besides, its physicochemical indices and shelf life was determined and the energy value was estimated.
\end{abstract}

\section{Introduction}

Poultry meat is a high-value food with its chemical composition, succulence, tenderness, nutritional value and dietary features.

Unlike the meats of other farm animals, the poultry meat contains much of muscle tissue and little of poorly developed connective tissue, hence, it comprises a great amount of complete proteins (15.8-24.5\%) and less amount of incomplete proteins (elastin, collagen).

Fat content in the poultry meat makes $11-16 \%$. Poultry fat has a low melting point $\left(36.5{ }^{\circ} \mathrm{C}\right)$, which stimulates its high assimilation in the body. Fats contain a number of unsaturated fatty acids, which are not sufficiently synthesized in the organism (linolenic, linoleic and arachidonic).

Poultry meat is close to slaughter animal meat regarding the quantity of mineral matters. It contains high amount of enzymes among which phosphatase, amylase, endoprotease, peroxidase and catalase are of high significance. Nitrogen-free extractive substances, which improve the meat flavor, constitute $1 \%$ of the poultry meat (glycogen, glucose, lactic acid) and are very important during meat ageing.

Meat is the main source of vitamin B complex for humans (Danilova, 2008). 
Nowadays, apart from the meat raw material, plant-based supplements are also widely used, which exert positive effect on the organoleptic indices, yield, production duration and other indices of the finished meat product.

Tea shrub is native to Asia. Camellia is a species of evergreen shrubs or small trees in the flowering plant family Theaceae. The main widely used varieties are Camellia sinensis, which is mostly used in China, Formosan and Japan, and the variety Assamica is mostly common in India.

Coffein constitutes $3 \%$ of the tea dry weight. In the tea mixture there is a considerable amount of polyphenol, which is a denser combination of leaves making up $30-40 \%$ of the mixture. Tea also contains small amounts of theobromine and theophylline.

Thyme is the herb (dried aerial parts) of some members of the genus Thymus of aromatic perennial evergreen plants or half-shrubs in the mint family Lamiaceae. It is widely spread and used by Armenian population. Thyme contains 0.5-1\% essential oils which comprise thymol, carvacrol, cymol, terpinene, borneol and zingiberene. It also contains chemical elements such as potassium, calcium, magnesium. For medicinal purposes the aboveground part of thyme is used, which is cut during the plants flowering period and dried out in the outdoor conditions. Thyme comprises vegetable gum, organic acids, flavonoids, vitamins $B$ and $C$.

Peppermint is a herbaceous rhizomatous perennial plant of the family Lamiaceae. The cultivated peppermint (Latin name - Mentha Piperita L.) has oval or lance-shaped leaves with inversely arranged, toothed acute margins and reddish small veins.

The aboveground mass of the plant contains essential oil, the amount of which in the flowers makes 4-6\%, in leaves they are $2.4-2.75 \%$ and in stalks - up to $0.3 \%$. It is produced out of the water vapors with infusion method. Its main constituent (41-65\%) is the secondary alcohol (41-65 \%) menthol. The plant also contains menton, pinene, limonene, dipentene, cineole and other valuable substances.

The plants leaves are used for medicinal purposes. Not only the herbal substances, but also the produced essential oil is used in medicine. Peppermint has been known to mankind from time immemorial. In medieval times there was an opinion that peppermint flavor activates the brain work.

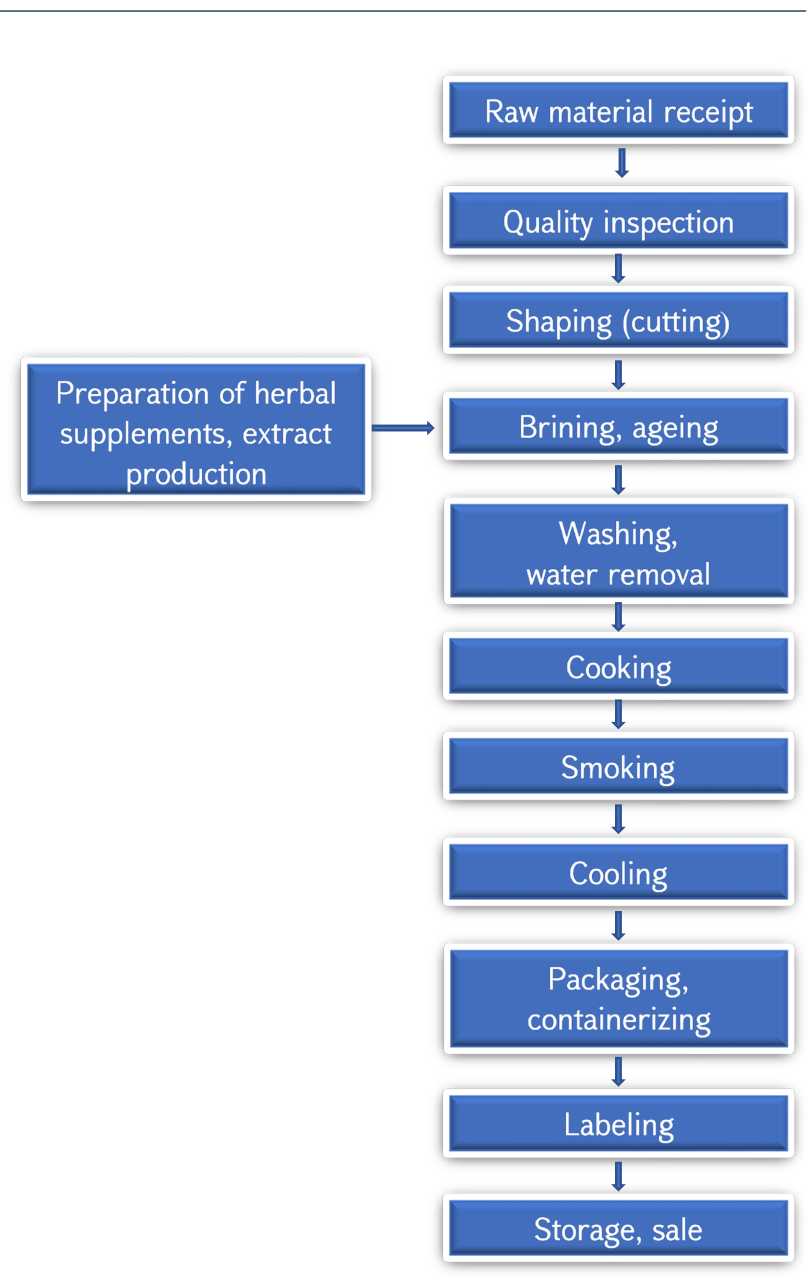

Diagram. Technological scheme for new smoked product manufacture (composed by the authors)

\section{Materials and methods}

The first stage of our investigations was implemented with the introduced technological scheme (Diagram).

The laboratory research and pilot experiments related to the current work have been conducted in the laboratory of the chair of "Animal-Based Foodstuff Processing Technology”, ANAU.

The organoleptic and physicochemical indicators of the finished product has been examined. The energy value of the meat product has been also estimated. The laboratory investigation of the manufactured product has been implemented in three replications and the arithmetic mean has been taken as a final outcome (Antipova, et al., 2001).

The new meat product has been manufactured from the raw material of local chicken meat. The meat carcass of the local broilers has been used as a raw material. 
As it has been already mentioned, along with the main raw material (chicken meat), tea plants have been also applied in the recommended technology for producing cured meat product, the water infusion of which has been used for raw material ageing.

After veterinary sanitary examination, the raw material (chicken meat) was subjected to physicochemical and organoleptic investigations, thereafter the raw material underwent cutting (splitting).

According to the raw material type the carcass was divided into 8 anatomical pieces, anyhow, the use of entire carcass and half-carcass is more preferable (Zonin, 2006).

After splitting the raw material, brining (salting) and ageing processes were simultaneously implemented. This process is the most important stage in the foodstuff production, since it determines the latter's flavor and qualitative indicators, as well as its shelf life.

In the result of multiple experiments the optimal salt amount in salt water was considered to be $2 \mathrm{~kg}$.

\section{Results and discussions}

As it has been already mentioned, tea plants have been used in the manufacture of new types of cured meat. It was mostly in the form of black tea, thyme and peppermint mixture. The optimal quantity of the tea plants has been determined, the results of which are introduced in Table 1. The calculation has been conducted for $100 \mathrm{~L}$ water. The results of numerous trials and the organoleptic indicators of the finished product have served as a background to identify the ratio of the tea plants mixture (Table 1).

Table 1. Determination of optimal quantity of tea plants*

\begin{tabular}{|l|c|c|}
\hline $\begin{array}{c}\text { Name of the tea } \\
\text { plant }\end{array}$ & $\begin{array}{c}\text { Quantity, } \\
\text { g }\end{array}$ & $\begin{array}{c}\text { Organoleptic } \\
\text { indicators }\end{array}$ \\
\hline Black tea & 500 & \\
\hline Thyme & 300 & $\begin{array}{c}\text { Well distinguished tea } \\
\text { plants taste and flavor } \\
\text { with yellowish tinge }\end{array}$ \\
\hline Peppermint & 150 & \\
\hline *Composed by the authors. & \\
\hline
\end{tabular}

So, the optimal salt water content per $100 \mathrm{~kg}$ raw material has been determined for the experimental sample:

Edible salt $-2 \mathrm{~kg}$

Sugar $-0.1 \mathrm{~kg}$
Black tea $-0.5 \mathrm{~kg}$

Thyme $-0.3 \mathrm{~kg}$

Peppermint $-0.15 \mathrm{~kg}$

After drawing out the brine ingredients the experimented samples were subjected to wet brining. The samples were submerged in the respective salt water at $2-4{ }^{\circ} \mathrm{C}$ and the process of their ageing was studied based on the taste, color, $\mathrm{pH}$ and consistency indexes.

Table 2. Brining and ageing indicators of the raw material*

\begin{tabular}{|c|c|c|c|}
\hline $\begin{array}{c}\text { Brining } \\
\text { duration, day }\end{array}$ & $\begin{array}{c}\text { Temperature, } \\
\mathbf{0}^{\mathbf{C}} \mathbf{C}\end{array}$ & $\boldsymbol{p H}$ & $\begin{array}{c}\text { Organoleptic } \\
\text { evaluation }\end{array}$ \\
\hline 1 & $2-4$ & 6.0 & $\begin{array}{c}\text { Thick consistency, } \\
\text { with light yellowish } \\
\text { color, poorly aged }\end{array}$ \\
\hline 2 & $2-4$ & 5.8 & $\begin{array}{c}\text { Stiff consistency, } \\
\text { intensely colored } \\
\text { (yellow-golden } \\
\text { tinge), well-aged }\end{array}$ \\
\hline 3 & $2-4$ & 5.6 & $\begin{array}{c}\text { Stiff consistency, } \\
\text { dark brown, } \\
\text { well-aged }\end{array}$ \\
\hline & & & \\
\hline
\end{tabular}

Based on the data of Table 2, the optimal brining and ageing time is considered to be 2 days, where the environmental $p H$ equaled to 5.8, consistency was firm with well-aged flavor and yellow-golden color. The further technological processes were implemented based on the traditional technological parameters of manufacturing smoked products from the chicken meat (http:/mirknig. com/). Taking into account that no preservation agents were applied during the food production the shelf life of the finished product has been set up from 3-4 days at the temperature of $0-6{ }^{\circ} \mathrm{C}$.

After developing the technology of the manufactured food product and determining the technological parameters (Table 3), the recipe of producing new type of smoked product from the poultry meat per $100 \mathrm{~kg}$ raw material was introduced (Table 4). 
Table 3. Production and storage parameters for new type of poultry meat product*

\section{Name of the products and actions}

Poultry raw material cutting,

half-carcass/semi-carcass

Optimal quantity of tea plants, $g$

Black tea

500

Thyme

300

Peppermint

150

Water amount, $L$

100

Infusion duration, $h$

3-4

Salt water/brine amount

Water, L

Edible salt, $\mathrm{kg}$

\section{Brining}

Brining, ${ }^{0} \mathrm{C}$

Duration, $\mathrm{h}$

\section{Cooking}

Temperature, ${ }^{0} \mathrm{C}$

Duration, $\mathrm{h}$

Temperature in the center of product, ${ }^{0} \mathrm{C}$

\section{Smoking/curing}

Temperature, ${ }^{0} \mathrm{C}$

Duration, h

\section{Cooling}

Temperature, ${ }^{0} \mathrm{C}$

Duration, $\mathrm{h}$

Temperature in the centre of product, ${ }^{0} \mathrm{C}$

Storage, sale

Temperature, ${ }^{0} \mathrm{C}$

Duration, $\mathrm{h}$
Table 4. The recipe of the finished product per $100 \mathrm{~kg}$ uncured raw material (poultry meat)*

\begin{tabular}{l|c|}
\hline \multicolumn{1}{|c|}{ Seasonings and agents } & Quantity, \\
\hline Edible salt & g \\
Sugar & 2000 \\
Black tea & 100 \\
Thyme & 500 \\
Peppermint & 300 \\
\hline *Composed by the authors. & 150 \\
\hline
\end{tabular}

The yield of finished product against the raw material makes $70-75 \%$. The finished product has been investigated per its humidity, protein, fat, mineral matters and edible salt content. The energy value of the new smoked product has been also estimated (Antipova, et al, MacCance \& Widdowson's Handbook, 2006).

The finished product was subjected to degustation and assessed with 30-point scale, getting scored with 28 points, which is considered as an excellent index for meat product. All investigations were conducted with triple replications and the arithmetic mean was assumed as the final result and recorded in Table 5 (Zonin, 2006).

Table 5. The summary indices of chemical composition and calorific value for the new smoked/cured product manufactured from the poultry meat*

\begin{tabular}{|c|c|c|c|c|c|}
\hline \multicolumn{4}{|c|}{$\begin{array}{c}\text { Content, } \\
\text { \% }\end{array}$} & \multicolumn{2}{c|}{$\begin{array}{c}\text { Energy } \\
\text { value }\end{array}$} \\
\hline Humidity & Protein & Fat & Ash $+\mathrm{NaCl}$ & $k c a l$ & $\mathrm{KJ}$ \\
\hline 50.33 & 22.57 & 22.41 & 4.69 & 291.97 & 1223.35 \\
\hline
\end{tabular}

*Composed by the authors.

The data of Table 5 indicate that in the investigated sample the protein $(22.57 \%)$ and fat $(22.41 \%)$ content is rather high, which provides the high calorific capacity (291.97 kcal) of the new type of smoked chicken meat product.

As it was stated in the tea plants description, they contain multiple enzymes, the activities of which result in the change of brine microflora. During the ageing process of the raw material, apart from enzymatic activities, lactic acid bacteria growth was also observed, which is proved upon the data on $p H$ (5.8) provided on the second day of ageing (Danilova, 2008).

During the brining period, changes in the poultry meat water absorption capacity also take place, which enables to state on the proper meat ageing course.

The research results have reaffirmed the miscellaneous beneficial properties of poultry meat and tea plants. The recommended technology is considered to be relevant, since such type of meat production ensures, first, utilization of local/domestic raw material, second - expansion of the meat product range and last but not least - manufacture of new type of meat food product. 


\section{Conclusion}

The effectiveness of applying poultry meat carcass in the production of the cured/smoked meat food is scientifically justified and experimentally proved. The use of tea plants in the smoked products manufacturing process is also well grounded upon the fact that they enhance the organoleptic indicators of the finished product.

The technological process and recipe for the manufacture of new meat product has been developed. It has been proved that during the mentioned food production process physicochemical changes take place which enhance the qualitative indices of the manufactured product. The latter is also endowed with high energy value which amounts to $291.97 \mathrm{kcal}$ and $1223.35 \mathrm{KJ}$. The new product has been also subjected to expert tasting as a result of which, it has scored 28 point in 30-point assessment scale. The developed production technology enables to reduce the ageing time in about 2 times, which promotes more efficient exploitation of production surfaces.

Thus, it is recommended to organize the manufacture of new meat product in the production units affiliate to the poultry factories.

\section{References}

1. Antipova L.V., L.V., Glotova, I.A., Rogov, I.A. (2001). Research Methods for Meat and Meat Products. - M .: Kolos, - 571 p.

2. Chemical Composition and Energy Value of Food Products. MacCance and Widdowson's Handbook (2006). Translated from English - SPB: Publishing House - Profession, - $560 \mathrm{p}$.

3. Danilova, N.S. (2008). Physico-Chemical Bases of Meat and Meat Products Manufacture: Textbook. - M .: Kolos, - 280 p.

4. http:/ mirknig.com/ knigi / profesii / 1184374071/ tehnologia-myasa-i-myasnyh-produktov (accessed on 08.02.2021).

5. Zonin, V.G. (2006). Contemporary Production of Sausage and Smoked Products. - Publishing House Profession, - 224 p. 